\title{
Financialization, Monetary Policy and Technological Innovation
}

\author{
Yang Cai ${ }^{1}$, Xiaojing $\mathrm{Hao}^{2}$, Enhao $\mathrm{Han}^{3,}$,, $\mathrm{Ke} \mathrm{Gao}^{4}$ \\ ${ }^{1}$ School of Management Science and Engineering, Central University of Finance and Economics, Beijing, P. R. China \\ ${ }^{2}$ School of Public Finance and Tax, Central University of Finance and Economics, Beijing, P. R. China \\ ${ }^{3}$ China Merchants Bank, Shanghai, P. R. China \\ ${ }^{4}$ Development Research Center of Shandong Provincial People's Government, Jinan, P. R. China
}

Email address:

61672064@qq.com (Enhao Han)

${ }^{*}$ Corresponding author

\section{To cite this article:}

Yang Cai, Xiaojing Hao, Enhao Han, Ke Gao. Financialization, Monetary Policy and Technological Innovation. Humanities and Social Sciences. Vol. 7, No. 1, 2019, pp. 1-13. doi: 10.11648/j.hss.20190701.11

Received: November 22, 2018; Accepted: January 17, 2019; Published: February 1, 2019

\begin{abstract}
Based on the research hotspot and the established status of the real economy financialization, this paper examines the impact of financialization on regional innovation from a macro perspective. In theory, economic financialization has an impact on regional innovation mainly through innovative "water reservoir effect" and "crowding effect", and the overall impact depends on the net effect of the two. In view of this, based on the 2008-2016 provincial panel data, this paper analyzes the specific effects of regional financialization on technological innovation and analyzes the transmission path of effects based on the spread of financial regions. The study finds that, on the whole, financialization has a negative overall effect on regional innovation, and this conclusion is still stable after using the instrumental variable test. After considering the spatial factors, the financialization has a positive and spatial relationship between the regions, indicating that the financialization has a tendency to spread between regions; at the same time, the impact of financialization on regional technological innovation is still significantly negative. Considering the location heterogeneity, it is found that the negative effects of financialization are more significant in the central and eastern regions. After further examining the monetary policy, it is found that the relatively loose monetary policy actually strengthens the "crowding out effect" and further worsens the suppression of innovation by financialization. The research of this paper supplements the relevant research on the development and impact of China's financialization at the macro level, and provides important empirical evidence for the government's guiding funds to "deviate from reality".
\end{abstract}

Keywords: Regional Financialization, Regional Innovation, Monetary Policy

\section{Introduction}

At present, China is at a critical stage of economic transformation. The development of enterprises, especially manufacturing enterprises, are gradually shifting from the "factor-driven" and "investment-driven" early development model to the "innovation-driven" development model. The success or failure of this transformation will also directly affect whether China can successfully cross the middle-income trap and enter the ranks of medium-developed countries. The central government also clearly proposed to implement an innovation-driven development strategy, emphasizing that technological innovation is a strategic support for improving social productivity and overall national strength ${ }^{1}$. For a long time in the past, the financial industry represented by the banking industry has maintained high growth and high profitability by relying on its monopoly

1Document No. 10 of 2015: "Several Opinions of the Central Committee of the Communist Party of China and the State Council on Deepening the Reform of System and Mechanism and Accelerating the Implementation of Innovation-Driven Development Strategy" 
advantage and interest rate control policy [1]. With the further saturation of market demand, the profit rate of the entity represented by the manufacturing industry has gradually declined. Under the general rule of capital profit-seeking, a large amount of industrial capital continues to flood into the financial industry with higher profit margins, prompting enterprises to deviate from the original main business, which in turn leads to the problem of "hollowing" of manufacturing. This is also known as the "Real Economy Financialization" [2]. In fact, foreign scholars have begun to pay attention to economic financialization earlier [3], and some believe that the main cause of the 2008 financial crisis is the excessive financialization of the economy [4].

Looking at the status quo, China's financial sector has contributed more to GDP than the United States and other development economies. In 2016, China's financial value added accounted for $8.22 \%{ }^{2}$ of GDP, higher than the US $7 \%$; At the same time, the profits obtained by the financial industry are also greater than those of other industries. In sharp contrast, the real economy sector, due to overcapacity, malicious competition, low-end of the industrial chain, etc., is developing very slowly, and there has been a serious imbalance between the real economy and the virtual economy [5]. Therefore, the Central Economic Work Conference put forward the "focus on revitalizing the real economy" as one of the key points of supply-side reform, that is, "to build a modern economic system, we must focus on the development of the real economy."

The financialization of the real economy is mainly manifested at the micro and macro levels. At the micro level, financialization is mainly manifested in the gradual active financial investment of entities: it can be found that in recent years, entity companies are increasingly investing industrial capital in stock investment and wealth management products. At the macro level, as the demand for corporate financial assets increases, the price of financial assets continues to rise, which will eventually lead to an increase in the proportion of value added in the regional financial industry. Figure 1 shows the trend of the proportion of financial value added in 30 regions of China between 2008 and 2016 .

According to Figure 1, the degree of financialization in China has been deepening in recent years, and the problem of the real economy being divisive is widespread.

Figure 2 uses the 2008 classification criteria as the benchmark classification criteria to examine the changes in the financial level of the provinces in 2008, 2011 and 2014. It can be seen that the level of financialization in China has shown a gradual deepening trend in various provinces, that is, the financial level of each province has increased year by year.

Rational use of financial markets and efficient allocation of financial capital are key to promoting technological innovation [6]. On the subject of this research, there has been some controversy over the impact of research on financialization. From the perspective of investment, there are two types of research, one is that financialization is easy to squeeze out existing investment; the other is based on the financing constraint that financialization can mitigate corporate investment. From the theoretical mechanism, financialization mainly replaces innovation through two ways. First, due to the financialization, the micro-subjects represented by enterprises have over-invested in financial assets in the investment process, and industrial investment has decreased accordingly. The innovation investment of enterprises attached to industrial investment has high-risk problems, so the corresponding corporate investment is also reduced. Given that external financing brought about by financing constraints is given, financial asset investment will inevitably lead to innovative investment by the underlying enterprise. Second, financialization will increase the investment expenditure of enterprises in the financial market and promote the repurchase of stocks by enterprises, thus inhibiting the innovative investment of enterprises. Specifically, the stock option-based compensation management system allows managers to increase their stock dividends in the short term and buy back a large number of stocks to drive up the stock price. At the same time, investors will force corporate managers to increase the dividend payout ratio. In the short term, due to personal interests and financial market pressure, corporate managers will satisfy stockholders' demand for high returns through stock dividends and stock repurchases.

Analysis of existing literature, some scholars believe that financialization can hollow out the real economy by absorbing and strengthening internal economic resources [7, 8]. The contradiction in manufacturing industry itself and the induction of high financial profits make the excessive financialization weaken the technological innovation capability of manufacturing enterprises [2]. In terms of mechanism, excessive financialization may lead to problems such as human resource mismatch and social credit misappropriation [9], which further affects enterprise innovation. This is also evidenced by the impact of financialization on unemployment [10].

Another group of scholars believe that financialization can promote the development of enterprises by alleviating the level of financing constraints of enterprises [11], so it can promote innovative investment of enterprises. The reason is that the former is a short-term investment behavior, and the "reservoir" effect enables companies to reduce financial distress costs by selling financial assets, thereby increasing investment [12], which can also promote enterprise innovation investment to some extent. 


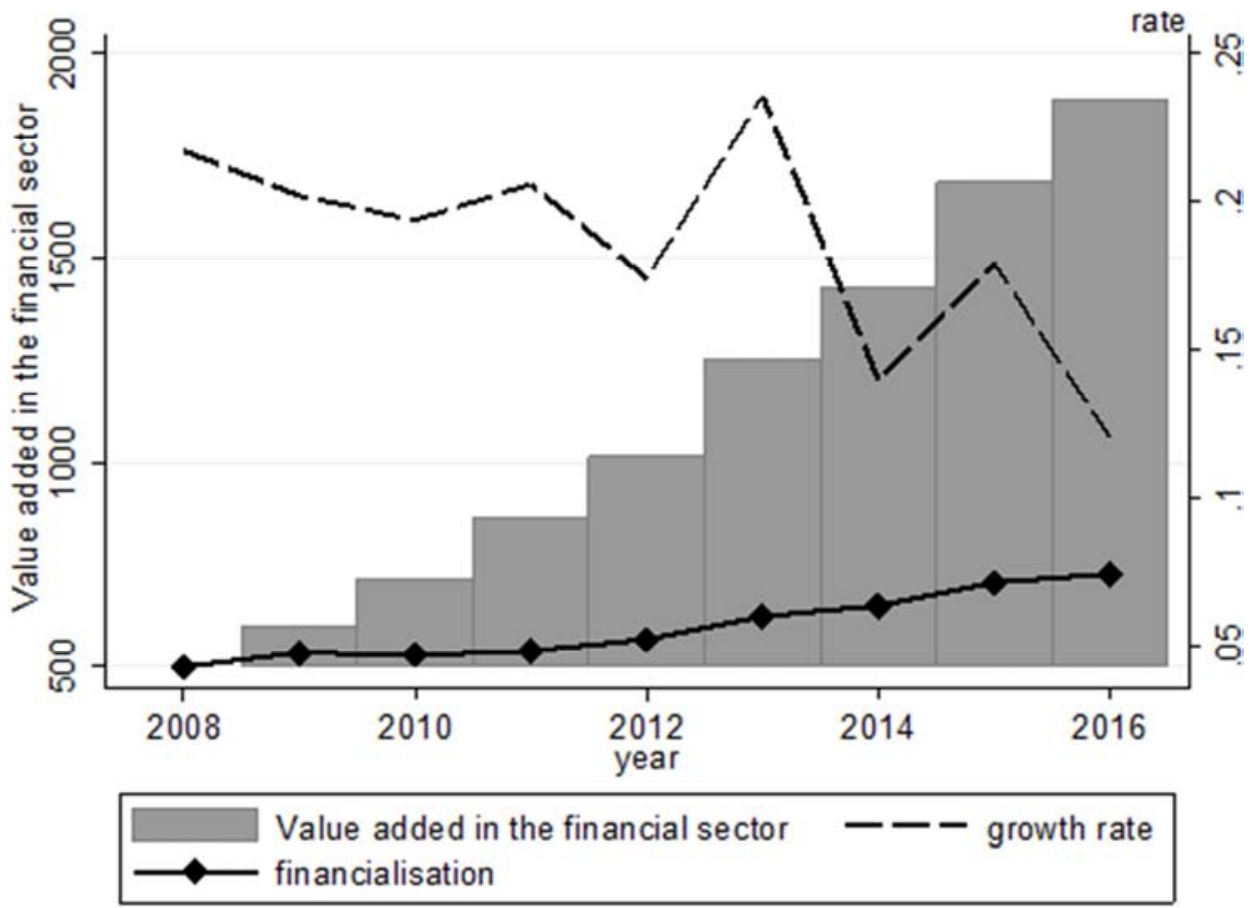

Figure 1. Average trend of financial value added in 30 regions of China ${ }^{3}$.

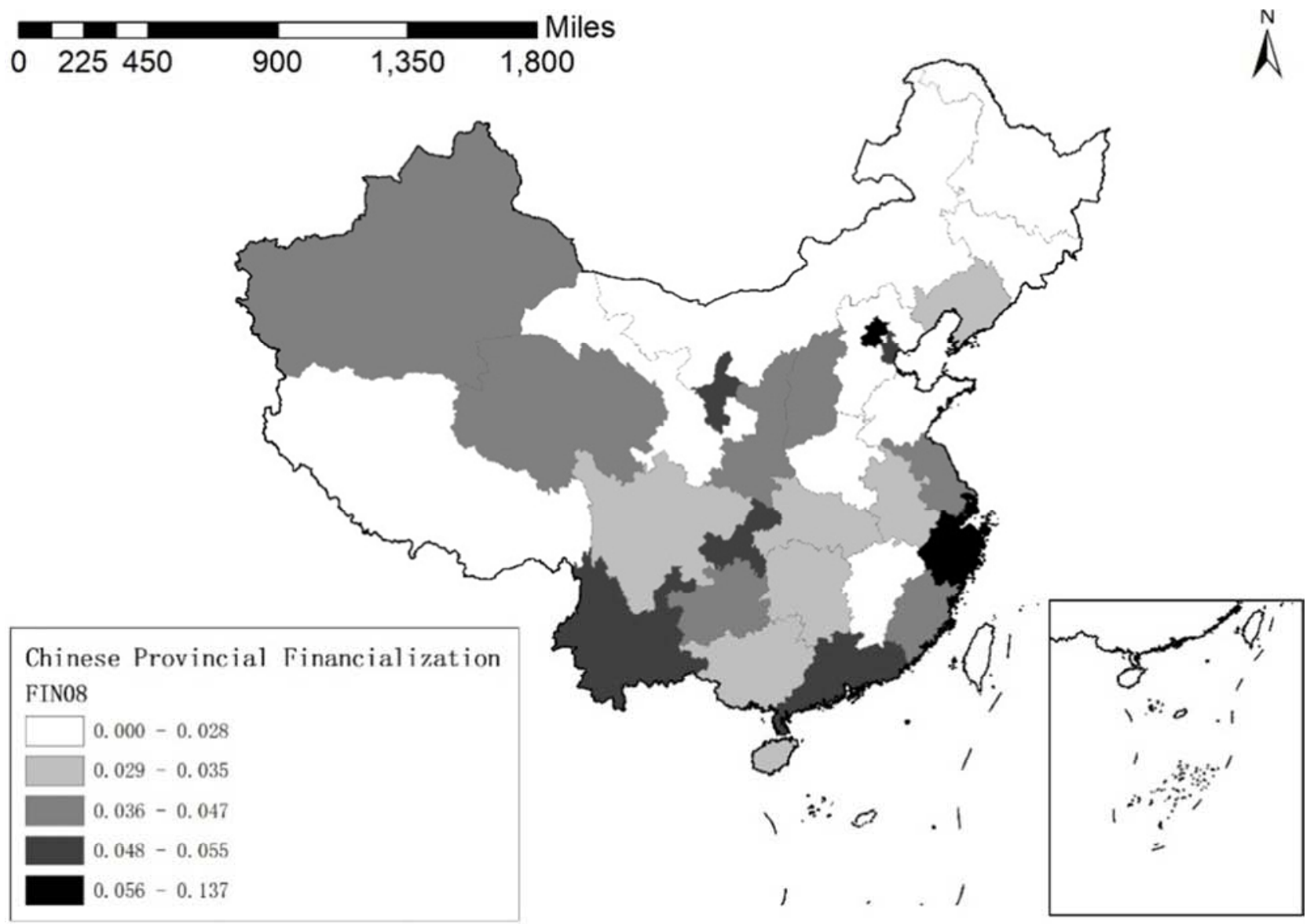

3Variable Calculating is based on the average value of financialization in 30 provinces over the years in China, including Beijing, Tianjin, Hebei, Shanxi, Inner Mongolia, Liaoning, Jilin, Heilongjiang, Shanghai, Jiangsu, Zhejiang, Anhui, Fujian, Jiangxi, Shandong, Henan, Hubei, Hunan, Guangdong, Guangxi, Hainan, Chongqing, Sichuan, Guizhou, Yunnan, Shaanxi, Gansu, Qinghai, Ningxia, Xinjiang. Growth rate = the change of value added in financial sector this period/value added in financial sector last period. Financialization=value added in financial sector/GDP. 


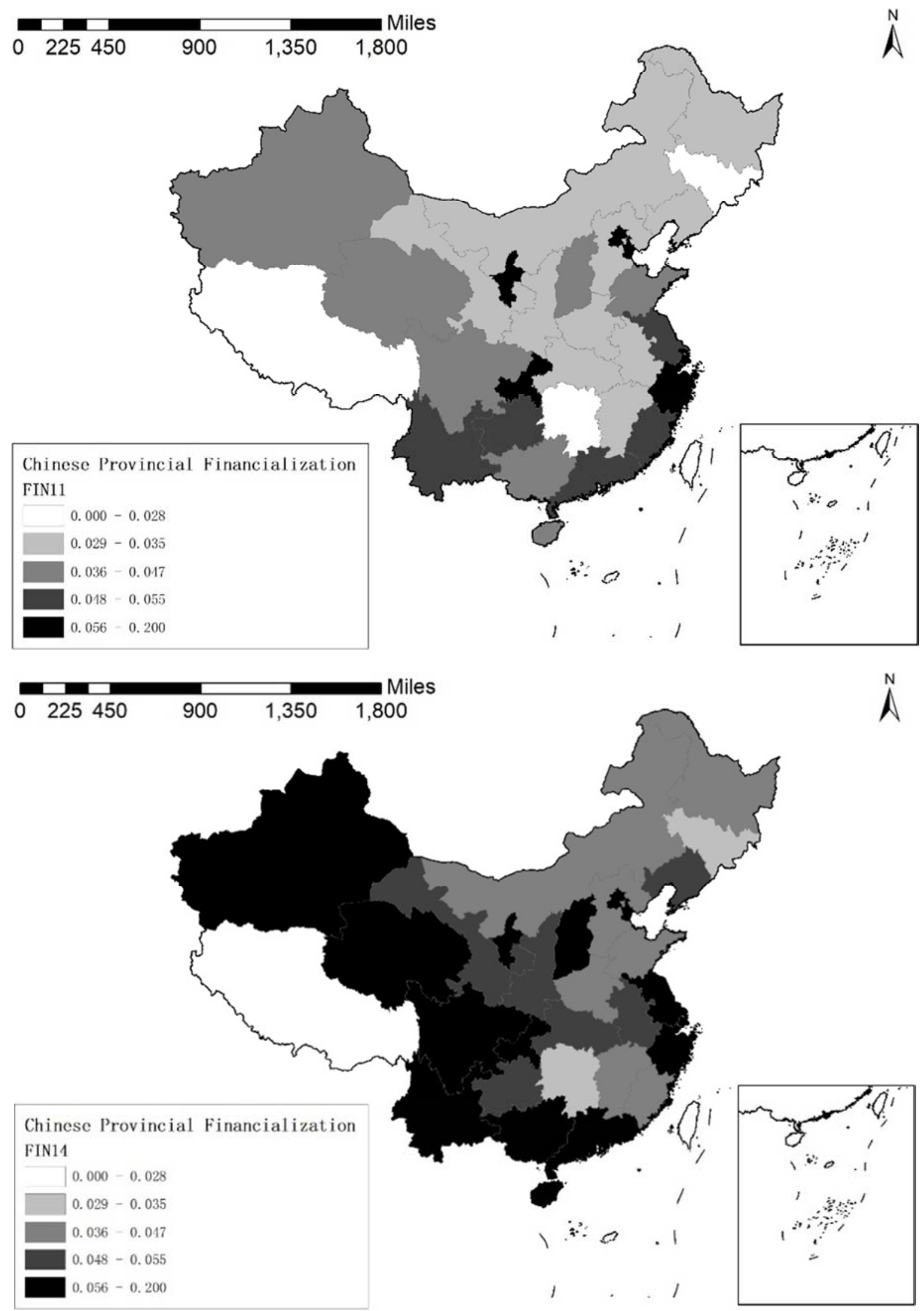

Figure 2. Changes in the level of financialization in various regions of China ${ }^{4}$.

4From top to bottom, it indicates the level of China's financialization in 2008, 2011 and 2014 respectively; the financial indicators are expressed by the GDP ratio of the added value of the financial industry; the classification in the figure is based on 2008, and the darker the color, the higher the degree of financialization. 
From a policy perspective, the "Regulatory Requirements for the Management and Use of Raised Funds of Listed Companies" "promulgated by the China Securities Regulatory Commission in 2012 allows listed companies to use idle funds to purchase investment products with high security and good liquidity. To a large extent, it has caused the level of financialization to rise after 2012. Concerned about the possible virtual economic bubble, the CSRC issued the "Regulations on Guiding and Regulating the Financing Behavior of Listed Companies" in February 2017, and pointed out that "when a listed company applies for refinancing, except for financial enterprises, in principle, there should be no trading financial assets and financial assets available for sale with large holding amount and long maturity, loans to others, and financial management such as entrusted wealth management are held." In the same year, the National Financial Work Conference also pointed out that financial needs to serve the real economy as a starting point and a foothold, which also shows the central government's concern about financialization issues.

Then, how financialization affects innovation and what mechanism influences innovation has good research value. This issue is closely related to the sustainability of China's innovation, and it is also related to the reshaping of financial policies. As a pilot research, this paper starts from the regional level, examines the problem of financialization spread between different regions, at the same time examines the main transmission mechanisms and the heterogeneous impact that financialization may have on regional innovation under different policy environments. The contributions of this paper relative to other studies are mainly concentrated on the following points: First of all, this paper starts from the regional level and examines the main influence of regional financialization on regional innovation; Secondly, it further considers the problem of financialization spread, analyzes the diffusion of financialization in different regions by using the spatial panel model, and discusses how the level of financialization affects regional innovation from the spatial dimension; Finally, combined with the macro policy, it analyzes how different policy variables affect the financialization-innovation relationship mechanism, which has certain reference significance for the formulation of China's monetary policy.

\section{Theoretical Analysis and Hypothesis}

Financialization refers to the tendency that the impact of financial investment on investment gradually deepens. A large number of theories and practices have shown that the financialization of industrial capital has greatly expanded the sources and channels of capital and enhanced the financing capacity of enterprises [13]. According to the endogenous growth theory, capital is an endogenous variable of enterprise

5The CSRC Announcement [2012] No. 44 "Regulations for the Supervision of Listed Companies No. 2 - Regulatory Requirements for the Management and Use of Funds Raised by Listed Companies". technology, and the development of finance and the process of financialization help to promote the technological innovation capability of manufacturing [14]. A good financial support system can provide large-scale financial support to the technological innovation system. The capital market promotes the long-term, stable and sustainable technological innovation behavior by providing long-term incentives, risk diversification and sharing opportunities for technological innovation investors. Therefore, the financialization process objectively plays a role in promoting technological innovation in manufacturing. It is precisely because of this that the manufacturing industry in developed countries has generally experienced a process of increasing financialization. However, with the strengthening of market mechanism and the deepening of financial development, industrial capital and financial capital have experienced a relatively complex evolution process, and some new features and development trends have emerged: With the advancement of the financialization process, the financial operation mode has undergone profound changes, which has affected the industrial capital and financial capital movement extensively and far-reachingly. The equilibrium of industrial capital and financial capital expansion has been gradually broken [2]. Excessive financialization will lead to changes in production patterns, boost the focus of economic activity from the industrial sector to the financial sector $[15,16,17]$, and in turn undermine the technological innovation base of manufacturing.

In the context of the rapid expansion of modern capital agglomeration capacity and production capacity, the manufacturing industry is prone to the situation of insufficient demand, overcapacity, and declining capital marginal investment returns [18]. As the profit of the main business of the manufacturing industry declines, the "excess" industrial capital is driven by profit, and the willingness to withdraw industrial capital for financial investment is enhanced. Compared with ordinary manufacturing, financial innovation costs are low and fast; and more importantly, the difference from the cost-supported price system of physical goods is that financial assets are conceptually supported price systems, and financial investments can create "asset prices" and "asset demand".

The financialization process promotes financial investment and financial speculation to form an endogenous circulatory system. The high profit rate drives the accumulation of financial capital and the investment thinking of financial profitability. In fact, the rapid expansion of financial capital has promoted the mutual penetration of financial capital and industrial capital, financial capital is no longer just in the form of borrowing capital, but mainly affects and even controls industrial capital through capital markets. Similarly, the capital market also plays an important role in the penetration of industrial capital into financial capital [19]. With the expansion of the degree of financialization of enterprises, the influence and control of financial capital on the manufacturing industry has increased, and more and more industrial profits 
and personal incomes have been absorbed, the decline in industrial profits has prevented new investments in factories and equipment. Therefore, whether the contradiction of the inherent development in manufacturing industry itself or the induction of external financial development, excessive financialization will weaken the technological innovation capability of manufacturing.

In addition, excessive financialization will further affect the company's governance structure. The promotion of "book value" by financialization may weaken the incentives for enterprises to innovate in technology. For example, the financialization of manufacturing will lead to a large number of cross-shareholdings and institutional investors' shareholding (or holding) manufacturing, which greatly affects the corporate governance structure. Institutional investors have become managers of large financial resources and have considerable influence in corporate governance [20]. Corporate decision-making in the context of financialization is increasingly influenced by external group preferences, including investors, regulators and other investors [21]. Corporate finance sacrifices the principle of autonomy of productive capital, and corporate investment decisions are increasingly subject to asset liquidity requirements $[15,22]$.

These factors attributed to the macro level can be expressed as the suppression of innovation and development in the regional financial level. In fact, after the honeymoon period in which the industrialization and financialization of manufacturing industries mutually promoted in Europe and the United States, since the 1980s, due to the decline in industrial economic profit margins, excess industrial capital has began to accelerate to financial investment with higher profit margins, financial capital has expanded relatively independently, and the development of advanced economies has entered a stage of high financialization and "de-industrialization" [23]. The excessive financialization of manufacturing accelerates the formation of the financial crisis and weakens the ability of innovation and development. Therefore, based on two types of views, the first theoretical hypothesis proposed in this paper is:

Hypothesis 1a: Regional financialization will inhibit the development of technological innovation;

Hypothesis 1b: Regional financialization will promote the development of technological innovation.

Traditional regional economics believes that there are spillover effects and reflux effects between inter-regional factors, so financial capital can spread to surrounding areas through these effects. From the perspective of spillover effects, financialization in different regions causes spillovers in other regions, thus strengthening the level of financialization in other regions. In general, the regional government may promote the financialization process at a certain level due to political considerations, which will eventually lead to the spread of financialization in different regions. From the enterprise level, because there are certain connections between enterprises in different regions or upstream and downstream enterprises in the industrial chain, enterprises may make corporate behavior decisions through organizational imitation [24]. Therefore, the financialization of enterprises may also spread through the imitation mechanism between enterprises. Of course, under the recirculation effect, regions with better financialization levels may attract financial resources from other regions, and thus the spatial effects of financialization may also have negative spatial effects. Therefore, based on the spatial contagion effect that financialization may produce, this paper further assumes that:

Hypothesis 2a: There is a positive spatialization effect of financialization between regions;

Hypothesis 2b: There is a negative financial diffusion effect between regions.

In the process of examining the impact of financialization on innovation, the consideration of China's policy environment is also very important. In general, loose monetary policy can reduce corporate financing interest rates, thereby promoting corporate fixed asset investment and boosting the real economy. Therefore, monetary policy indicators are generally important control variables in corporate investment decision-making models [25]. Monetary policy affects corporate innovation activities, mainly driven by supply. There are three main reasons for this point: First, most studies believe that China's monetary policy mainly plays a role through credit channels [26, 27]. Moreover, since China's interest rates have not yet fully realized marketization, such credit channels often lend to enterprises through credit rationing, and the price mechanism has a limited effect. Second, under the banking system dominated by China's banks, compared with the capital-demanding enterprises, banks have lower competitive pressures as capital supply and can dominate the credit contract. When the monetary tightening, banks pay more attention to the central bank's credit control requirements, rather than the actual business needs of the company. Finally, innovative investment has heterogeneous characteristics such as high risk and high asset specificity, which aggravates the information asymmetry between the fund supply and demand sides, making enterprise innovation investment more dependent on internal funds [28]. In the case of tight monetary conditions, banks are paying more attention to capital security. In order to strengthen risk control, the willingness to lend to innovative companies and their innovative investments will fall, and more stringent contract terms will be proposed, which further aggravates the financing constraints and thus affects the investment activities and innovative investment levels of innovative enterprises.

In short, when the central bank implements a loose monetary policy, increased currency issuance will promote credit. The loan provided by the commercial bank to the enterprise will not only increase the amount of the loan, but also decrease the loan interest accordingly. This means that loose monetary policy can help companies obtain more external debt capital at lower financing costs. The increase in corporate investment tendencies usually accelerates the level of investment in innovation. Therefore, based on this logic, in the loose monetary environment, the development of China's real economy will be further accelerated, and the level of 
enterprise innovation investment will be further enhanced.

However, in recent years, the liquidity provided by China's easing policy has not spurred the real economy and enterprise innovation. On the contrary, there have been phenomena such as "de-solidification" of funds and "hollowing" of the physical sector. Due to the high rate of return on financial assets, companies may be more inclined to invest in financial assets than corporate innovation with high risk. In the stage of relatively loose monetary policy, a large amount of credit will flood into the market. Based on the arbitrage mechanism, it is easier to use pledge capital to purchase financial assets for arbitrage [29]. This behavior may further lead to an increase in the level of corporate financialization. At the regional level, it will be reflected in the rising value of regional financial added value. This will further reduce the company's willingness to invest in industry and innovation, leading to further reductions in innovation investment. In general, the impact of monetary policy on corporate innovation can rely on the financialization path of enterprises to judge the impact of innovation. However the overall effect of how to influence remains to be seen. Therefore, based on the above ideas, this paper further proposes the following two hypotheses:

Hypothesis 3a: A relatively loose monetary policy environment will exacerbate the overall negative effects of regional financialization, thereby inhibiting regional innovation investment;

Hypothesis 3b: A relatively loose monetary policy environment will weaken the overall negative effects of regional financialization, thereby promoting regional innovation investment.

\section{Research Design}

\subsection{Measurement Model}

Based on the research hypothesis proposed above, the measurement model designed in this paper focuses on the relationship between regional financialization and regional innovation. Based on this logic, the model is designed as follows:

$$
\text { innovation }_{i t}=\beta_{0}+\beta_{1} \text { Fin }_{i t}+\beta_{i+1} \sum Z_{i t}+\varepsilon_{i t}
$$

$i$ represents the province and $t$ represents the year; innovation represents an indicator of regional innovation level; Fin represents the level of financialization in the region; $Z$ represents a set of control variables; $\varepsilon$ represents a random disturbance term.

\subsection{Variables Selection and Description}

\subsubsection{Dependent Variable}

The dependent variable of this paper is used to measure the overall level of provincial technological innovation activities. Selecting and measuring it is an important step in this research topic. Previous studies have generally measured the level of technological innovation from multiple dimensions such as inputs, processes, and outputs $[30,31]$. On the basis of the original literature, taking into account the main mechanism of financialization affecting innovation, from the perspective of innovation investment, this paper uses the proportion of innovation investment of enterprises above designated size to GDP to measure the innovation level in different regions. The data source is the National Bureau of Statistics database. The main reasons for using this variable as an innovation variable are: First, the mechanism for financial impact innovation is usually through the injection of innovative investments in the region. Therefore, the most direct impact of financialization is the level of innovation investment in different regions. The use of this variable is also in line with the logical intuition of this paper. On the other hand, after standardization of GDP, it can eliminate the incomparable factors caused by factors such as economic volume in different regions. At the same time, in order to ensure the robustness of the results, this paper further tests the robustness test from the perspective of human resources investment by investing the full-time equivalents as a substitute for regional innovation. The data source is also the National Bureau of Statistics database.

\subsubsection{Independent Variable}

Domestic and foreign literatures have many different financial metrics from different perspectives. Among them, King \& Levine measured the level of economic monetization of a country by (M3-M1) / GDP [32]; Levine reflected the degree of securitization by the total market capitalization of the stock /GDP to measure the level of financialization [33]; Epstein measured the degree of financialization by the proportion of financial assets profits to national wealth [15]; Palley measured the level of financialization in the United States by using the proportion of output value of finance, insurance and real estate sectors to GDP [34]; Domestic scholar Xu used bank credit/GDP as a surrogate indicator to reflect the degree of financialization in China [35]; Zhang measured the evolution of China's financialization by the contribution rate of financial sector and FIRE industry to GDP [36]. In fact, with China's economic transition and the gradual improvement of market economic system, the financial assets are continuously enriched, and the financial system is well established, the role played by the financial sector in the national economic system continues to rise. At the industrial level, economic financialization shows an increase in the proportion of financial industry in the national economic system. In summary, economic financialization ultimately reflects the expansion of the financial sector, the securitization of physical assets, It is more inclined to use financial assets to create profits. Therefore, based on the comprehensive perception of the concept, the proportion of the added value of the financial industry in GDP is used to measure the level of financialization in the region. The data is from the National Bureau of Statistics database, and the time interval is 2008-2016. The reasons for choosing this time interval are two points: one is the availability of data; the other is that this time interval is conducive to exploring the characteristics of China's financialization in the post-financial crisis era, and examining the staged evidence of the impact of 
financialization on innovation.

\subsubsection{Control Variable}

Testing the impact of financialization on regional innovation can only be achieved after a series of related variables controlled. Control variables are mainly concentrated at the macro level. First of all, this paper chooses per capita freight volume as the main indicator to measure regional infrastructure; budgetary fiscal expenditure/budgetary revenue issued to measure fiscal autonomy; the logarithmized per capita GDP is used as an indicator to measure the level of regional economic development. Considering that the financialization is easy to squeeze out the innovation investment of the manufacturing industry, the control variables include the current industrial structure variables in China, mainly using the ratio of the output value of the secondary production after GDP standardization. These data are mainly from the national statistical database. Further, the marketization index comes from Wang and Fan's "China's Provincial Marketization Index Report (2016)". Since the data interval is 2008-2014, the space panel is required to be a balance panel in the process of measuring the space panel, so this paper eliminates the year containing the empty data. In addition, many literatures have found that FDI has a positive or negative impact on local technological innovation, so this article further includes FDI variables in the control variables. Since the FDI data unit is different from the GDP unit, this paper uses the monthly average exchange rate of the year to convert the FDI. Ultimately, this variable is measured by FDI/GDP in each province. The variables and descriptive statistics involved in the specific model are shown in Table 1.

Table 1. Model variable definition and descriptive statistics.

\begin{tabular}{|c|c|c|c|c|c|c|}
\hline & Variable symbol & Variable name & Approach & Mean & Minimum & Maximum \\
\hline \multirow{5}{*}{$\begin{array}{l}\text { Dependent } \\
\text { variable } \\
\text { Independent } \\
\text { variable }\end{array}$} & innovation $_{i t}$ & $\begin{array}{l}\text { Regional innovation } \\
\text { index }\end{array}$ & $\begin{array}{l}\text { R\&D in enterprises above designated size / } \\
\text { GDP }\end{array}$ & 0.0094 & 0.0005 & 0.0214 \\
\hline & $\operatorname{fin}_{i t}$ & Financialization index & Financial added value / GDP & 0.0564 & 0.0187 & 0.1705 \\
\hline & infrastructure $_{i t}$ & Infrastructure index & Total freight / total population & 28.337 & 9.0912 & 76.594 \\
\hline & industry $_{i t}$ & Industrial structure index & Secondary industry output value / GDP & 0.4699 & 0.1926 & 0.6150 \\
\hline & $f d_{i t}$ & $\begin{array}{l}\text { Financial autonomy } \\
\text { index }\end{array}$ & $\begin{array}{l}\text { Budgetary fiscal expenditure / budgetary } \\
\text { revenue }\end{array}$ & 2.2640 & 1.0663 & 6.7446 \\
\hline \multirow{3}{*}{$\begin{array}{l}\text { Control } \\
\text { variable }\end{array}$} & market $_{i t}$ & Marketization index & $\begin{array}{l}\text { According to the "China's Provincial } \\
\text { Marketization Index Report (2016)" }\end{array}$ & 6.000 & 2.5300 & 9.9500 \\
\hline & $f d i_{i t}$ & $\begin{array}{l}\text { Foreign investment } \\
\text { index }\end{array}$ & FDI/GDP & 0.3481 & 0.0473 & 4.5015 \\
\hline & $a g d p_{i t}$ & Per capita GDP & Logarithmic GDP per capita & 10.529 & 9.2007 & 11.679 \\
\hline
\end{tabular}

\subsubsection{Endogenous Problems and Instrumental Variables}

In general, there are two main endogenous problems: one is that the explanatory variable and the explanatory variable have a causal relationship; the other is that there is a missing item. In this paper, from the perspective of the relationship between the two, the accumulation of wealth through technological innovation in the region may affect the future asset allocation and investment decisions of the enterprise to a certain extent, thus affecting the level of financialization. It can be argued that there is an endogenous connection between the two. In addition, there are still many missing variables. This paper uses the financialization variables of the first and second order of lag as the instrumental variable group. In the estimation, the validity of the instrumental variables was tested.

\section{Empirical Results}

According to the baseline regression model, the regression results are shown in Table 2. The results in Table 2 show that financialization has a significant inhibitory effect on regional innovation without the use of instrumental variables. This article uses the financialization index of the first-order and the second-order lag as the instrumental variable group, and use the 2SLS method to re-estimate the results. The regression results show that regional financialization still has a significant negative effect on regional technological innovation activities. The results of models (3) and (4) show that whether or not control variables are added, the negative impact of financial indicators on technological innovation is robust regardless, and a $1 \%$ significance test is passed.

Considering the instrumental variables, the first-stage regression results of 2 SLS indicate that the instrumental variables pass the correlation test. At the same time, this paper also performs weak identification test (Kleibergen-Paap LM), weak tool variable test (Cragg-Donald Wald F) and over-identification test (Sargan-Hansen J), the results show that the tool variable group is valid.

Considering the control variables, regions with strong fiscal autonomy can significantly promote innovation investment, indicating the importance of fiscal policy in promoting regional innovation. At the same time, there is a strong positive correlation between marketization index and innovation, indicating that the degree of marketization can significantly promote innovation investment in the region. In addition, it can be found that per capita GDP has a significant negative impact on innovation. The reason for this result may be that the regions with higher per capita GDP are usually developed regions, and the degree of financialization is relatively higher, which may have a negative impact on regional innovation. 
Table 2. Basic regression of financialization and regional innovation.

\begin{tabular}{lllll}
\hline \multirow{2}{*}{ Model } & $\mathbf{( 1 )}$ & $\mathbf{( 2 )}$ & $\mathbf{( 3 )}$ & $\mathbf{( 4 )}$ \\
\cline { 2 - 5 } & OLS & & 2SLS & innovation \\
\hline Dependent Variable & innovation & innovation & $-0.056^{* * *}(0.014)$ & $-0.046^{* * *}(0.017)$ \\
\hline fin & $-0.061^{* * *}(0.017)$ & $-0.056^{* * *}(0.018)$ & $-0.000(0.000)$ \\
infrastructure & & $0.000(0.000)$ & $0.003(0.005)$ \\
industry & & $0.005(0.004)$ & $-0.002^{* *}(0.001)$ \\
fd & & $-0.001(0.000)$ & $0.001^{* * *}(0.000)$ \\
market & & $0.001^{* * *}(0.000)$ & & $-0.002^{* * *}(0.001)$ \\
fdi & & $0.000(0.000)$ & $-0.003(0.002)$ \\
agdp & YES & $-0.004^{* *}(0.002)$ & & YES \\
Provincial Fixed Effect & YES & YES & YES \\
Time Fixed Effect & & YES & YES & $17.541(0.000)$ \\
Kleibergen-Paap LM (p-value) & & & $16.516(0.000)$ & 25.725 \\
Cragg-Donald Wald F & & & 38.463 & 19.93 \\
Stock-Yogo-10\% & & & 19.93 & $1.609(0.205)$ \\
Sargan-Hansen J (p-value) & & $0.073(0.787)$ & 0.985 \\
$\mathrm{R}^{2}$-adj & 0.887 & 0.896 & 0.982 & 180 \\
Obs. & 270 & 270 & & 180 \\
\hline
\end{tabular}

Note: $* * *, * * *$ means passing the $10 \%, 5 \%, 1 \%$ significance test respectively; The standard deviation is in brackets.

\section{The Spatial Effect Test of the Spread of Financialization}

\subsection{Model}

Next, this paper incorporates spatial factors into the impact of financialization on regional innovation to test the role of financialization spread in regional innovation. The spatial econometric model can be divided into spatial autoregressive model (SAR), spatial Dubin model (SDM), spatial error model (SEM), and spatial autocorrelation model (SAC). The panel data used in this paper considers both spatial and temporal factors. Therefore, based on the original spatial panel estimation model, this paper further uses the spatial dynamic panel model to explain the impact of financialization on regional innovation. Among them, the judgment of the spatial model is based on the rules of Anselin et al. (2004), and finally the SDM model is used as the final analysis model. Set the model as follows:

$$
\begin{aligned}
\text { innovation }_{i t}= & \delta_{0}+\rho W_{i j} \text { innovation }_{i t}+\delta_{1} \text { Fin }_{i t}+\gamma_{1} W_{i j} \text { Fin }_{i t}+\gamma \sum W_{i j} C_{i t}+ \\
& \delta \sum C_{i t}+u_{i t}+\tau_{i t}+\varepsilon_{i t}
\end{aligned}
$$

In model (2), $i$ denotes different regions; $t$ denotes year; innovation denotes innovation indicators in different regions; $C$ denotes control variables; $W$ denotes spatial weight matrix; $u, \tau, \varepsilon$ denote individual effects, time effects, and random error. In this part of the analysis, this article includes three types of spatial weight matrices: (1) Adjacency matrix: the adjacency matrix is $(0,1)$ matrix, the adjacent two regions are 1 and the non-adjacent two are 0 ; (2) Geographic distance matrix: the matrix is constructed by using the reciprocal of the square of the geographic distance between the unit $i$ and the unit $j$; (3) Gravitational Matrix: Using the logic of the general gravity model, the spatial weight matrix is constructed by the ratio of the product of two places' per capita GDP to the square of the geographic distance between the two places. The three types of matrices are expressed as:

$$
\begin{aligned}
& W_{i j}^{a}=\left\{\begin{array}{l}
1 \\
0
\end{array} ; \quad W_{i j}^{\text {adjacent }}=\frac{W_{i j}^{d}}{\sum W_{i j}^{d}}, i \neq j\right. \\
& W_{i j}^{d}=\frac{1}{d_{i j}^{2}} ; \quad W_{i j}^{\text {distance }}=\frac{W_{i j}^{d}}{\sum W_{i j}^{d}}, i \neq j
\end{aligned}
$$

$$
W_{i j}^{g}=\frac{E_{i} \times E_{j}}{d_{i j}^{2}} ; \quad W_{i j}^{\text {gravity }}=\frac{W_{i j}^{g}}{\sum W_{i j}^{g}}, i \neq j
$$

Where $d_{i j}$ is the geographical distance between the $i$ and $j$ regions; $E_{i(j)}$ is the per capita GDP of the region $i(j)$. The GDP indicators are all deflated in 2008. $W^{\text {adjacent }}, W^{\text {distance }}$ and $W^{\text {gravity }}$ represent three types of spatial weight matrices after standardization.

\subsection{Spatial Panel Regression Results}

First of all, this paper verifies the spread characteristics of financialization, that is, whether there is inter-regional correlation in financialization. Table 3 reports the Moran' I index. It can be seen that in different years, both the absolute estimator and the relative estimator of financialization show a positive spatial correlation, and basically pass the $5 \%$ significance test, which indicates that there is indeed space spread in financialization. That is, the rise of the level of financialization in a region can drive the level of financialization in neighboring regions, and this result also proves Hypothesis $2 \mathrm{a}$. 
Further, Table 4 reports the estimation results of various spatial weight estimation models. According to the model (1)-model (6), whether using the static space model or the dynamic space model, the financial indicators are significantly negative at least at the $10 \%$ level, and the coefficients have strong consistency. Hence, the conclusion that the negative effect of financialization on regional innovation is still stable after considering the spatial factors, it further validates Hypothesis 1a.

Table 3. Characteristics of financialization spread in 2008-2016.

\begin{tabular}{|c|c|c|c|c|c|c|c|c|c|}
\hline Year & 2008 & 2009 & 2010 & 2011 & 2012 & 2013 & 2014 & 2015 & 2016 \\
\hline Moran-W $W^{\text {adjacet }}$ & $0.133(0.105)$ & $\begin{array}{l}0.166^{*} \\
(0.110)\end{array}$ & $0.180 *(0.110)$ & $0.199 * *(0.111)$ & $0.192 * *(0.112)$ & $\begin{array}{l}0.157 * \\
(0.111)\end{array}$ & $\begin{array}{l}0.144 \\
(0.109)\end{array}$ & $\begin{array}{l}0.067 \\
(0.109)\end{array}$ & $\begin{array}{l}0.043 \\
(0.110)\end{array}$ \\
\hline Moran- $\mathrm{W}^{\text {distance }}$ & $0.151 * *(0.081)$ & $\begin{array}{l}0.172 * * \\
(0.085)\end{array}$ & $0.186 * *(0.085)$ & $0.204 * * *(0.085)$ & $0.205 * * *(0.086)$ & $\begin{array}{l}0.164 * * \\
(0.086)\end{array}$ & $\begin{array}{l}0.131 * * \\
(0.084)\end{array}$ & $\begin{array}{l}0.067 \\
(0.084)\end{array}$ & $\begin{array}{l}0.046 \\
(0.085)\end{array}$ \\
\hline Moran-W $\mathrm{W}^{\text {gravity }}$ & $0.133 * *(0.080)$ & $\begin{array}{l}0.161 * * \\
(0.084)\end{array}$ & $0.178 * *(0.084)$ & $0.198 * * *(0.084)$ & $0.197 * * *(0.085)$ & $\begin{array}{l}0.144 * * \\
(0.084)\end{array}$ & $\begin{array}{l}0.107 * \\
(0.083)\end{array}$ & $\begin{array}{l}0.035 \\
(0.083)\end{array}$ & $\begin{array}{l}0.012 \\
(0.084)\end{array}$ \\
\hline
\end{tabular}

Note: $* * *, * * *$ means passing the $10 \%, 5 \%, 1 \%$ significance test respectively; The standard deviation is in brackets.

Table 4. Spatial panel regression of financialization and regional innovation.

\begin{tabular}{|c|c|c|c|c|c|c|}
\hline Model & (1) & (2) & (3) & (4) & (5) & (6) \\
\hline Model Matrix & SDM W $\mathbf{W}^{\text {adjacent }}$ & SDM W $\mathbf{W}^{\text {distance }}$ & SDM W $\mathbf{W}^{\text {gravity }}$ & $\begin{array}{l}\text { Dynamic SDM } \\
\text { W }^{\text {adjacent }}\end{array}$ & $\begin{array}{l}\text { Dynamic SDM } \\
\text { W }^{\text {distance }}\end{array}$ & $\begin{array}{l}\text { Dynamic SDM } \\
\text { W }^{\text {gravity }}\end{array}$ \\
\hline Dependent & innovation & innovation & innovation & innovation & innovation & innovation \\
\hline L. innovation & & & & $0.288 * * *(0.062)$ & $0.284 * * *(0.061)$ & $0.294 * * *(0.062)$ \\
\hline fin & $-0.059 * * *(0.019)$ & $-0.053 * * *(0.020)$ & $-0.055 * *(0.022)$ & $-0.049 * *(0.020)$ & $-0.041 * *(0.020)$ & $-0.041 *(0.022)$ \\
\hline infrastructure & $0.000(0.000)$ & $0.000(0.000)$ & $0.000(0.000)$ & $0.000(0.000)$ & $0.000(0.000)$ & $0.000(0.000)$ \\
\hline industry & $0.003(0.009)$ & $0.004(0.010)$ & $0.004(0.010)$ & $-0.003(0.011)$ & $-0.002(0.011)$ & $-0.001(0.012)$ \\
\hline market & $0.001 * * *(0.000)$ & $0.001 * * *(0.000)$ & $0.001 * * *(0.000)$ & $0.001 * * *(0.000)$ & $0.001 * * *(0.000)$ & $0.001 * * *(0.000)$ \\
\hline$f d i$ & $0.000(0.000)$ & $-0.000(0.000)$ & $-0.000(0.000)$ & $-0.000(0.000)$ & $-0.000(0.000)$ & $-0.000(0.000)$ \\
\hline$a g d p$ & $-0.005(0.004)$ & $-0.004(0.004)$ & $-0.005(0.004)$ & $-0.005(0.004)$ & $-0.004(0.003)$ & $-0.005(0.003)$ \\
\hline Provincial Effect & YES & YES & YES & YES & YES & YES \\
\hline Time Effect & YES & YES & YES & YES & YES & YES \\
\hline $\log L$ & 1357.105 & 1357.267 & 1350.522 & 981.581 & 1069.034 & 1004.338 \\
\hline Obs & 270 & 270 & 270 & 240 & 240 & 240 \\
\hline
\end{tabular}

Note: $* * *, * * *$ means passing the $10 \%, 5 \%, 1 \%$ significance test respectively; The standard deviation is in brackets.

\subsection{Regional Heterogeneity}

Table 5 reports the impact of financialization on regional innovation in different regions of the eastern, central and western based on spatial effects. It can be found that only in the eastern region, financialization is significantly negative for regional innovation under the three types of spatial weight matrix at least above 5\%; Further comparison coefficient can be found that the negative impact of financialization in the eastern region is greater than that in the central region and the western region. Based on this, it can be judged that in the relatively developed regions, excessive financialization has further expanded the original "crowding out effect" and eventually caused financialization to curb the technological innovation and development of the region. In general, despite the heterogeneity at the regional level, but the results of innovation in financial suppression regions remain stable.

Table 5. Regional differences in the impact of financialization.

\begin{tabular}{llll}
\hline East & & & \\
Dependent & Innovation $\mathrm{W}^{\text {adjacent }}$ & Innovation $\mathrm{W}^{\text {distance }}$ & Innovation $\mathrm{W}^{\text {gravity }}$ \\
fin & $-0.066^{* * *}(0.019)$ & $-0.087^{* * *}(0.024)$ & $-0.083^{* *}(0.028)$ \\
Control Variable & YES & YES & YES \\
Provincial Effect & YES & YES & YES \\
Time Effect & YES & YES & YES \\
LogL & 516.888 & 515.381 & 509.941 \\
Obs. & 88 & 88 & 88 \\
Middle & & & Innovation $\mathrm{W}^{\text {gravity }}$ \\
Dependent & Innovation $\mathrm{W}^{\text {adjacent }}$ & Innovation $\mathrm{W}^{\text {distance }}$ & $-0.039(0.024)$ \\
fin & $-0.066^{* * *}(0.025)$ & $-0.031(0.025)$ & YES \\
Control Variable & YES & YES & YES \\
Provincial Effect & YES & YES & YES \\
Time Effect & YES & YES & 408.176 \\
LogL & 401.814 & 408.382 & 64 \\
Obs. & 64 & 64 & \\
\hline
\end{tabular}




\begin{tabular}{llll}
\hline West & & & Innovation $\mathrm{W}^{\text {adjacent }}$ \\
Dependent & $-0.030^{* *}(0.013)$ & Innovation $\mathrm{W}^{\text {distance }}$ & $-0.019(0.014)$ \\
fin & YES & $-0.016(0.014)$ & YES \\
Control Variable & YES & YES & YES \\
Provincial Effect & YES & YES & YES \\
Time Effect & 566.015 & YES & 558.487 \\
LogL & 88 & 560.368 & 88 \\
Obs. & 88 & 88 \\
\hline
\end{tabular}

Note: $*, * *, * *$ means passing the $10 \%, 5 \%, 1 \%$ significance test respectively; The standard deviation is in brackets.

\section{Monetary Policy Effect and Impact Mechanism Test}

As an important means for the central bank to carry out macroeconomic regulation and control of the financial market, and accomplish the goal of national economic development, monetary policy is of great significance in the financial system. How to measure the effectiveness of monetary policy and further understand the operational mechanism of monetary policy is also important. At the theoretical level, it has been explained that the possible impact of monetary policy on corporate innovation. At the same time, further combined with the transmission path of financialization, monetary policy may weaken or aggravate the impact of financialization on innovation. However, the actual impact needs to be further tested.

Here, it will be examined how monetary policy affects regional innovation through the path of financialization. Taking into account monetary policy variables, Zhu and $\mathrm{Lu}$ used the monetary policy perception index provided by "Banker Questionnaire”, which was jointly completed by the People's Bank of China and the National Bureau of Statistics, to measure the tightness of monetary policy [37], but the index still has a strong subjective component. In view of this, this paper sets the following two dummy variables (currency 1, currency 2) to measure the relatively loose or tight of monetary policy: (1) currency 1: Measured by the growth rate of $\mathrm{M} 2$, the sample above the median is set to 1 (including the median) and the rest is 0 . (2) currency 2 :
Using the difference between the M2 growth rate minus the GDP growth rate minus the CPI growth rate, the median above the sample is set to 1 (including the median) and the rest is zero. Therefore, the monetary policy for the year set to 1 is relatively loose, and the monetary policy for the year set to 0 is relatively tight. In addition to directly including this dummy variable, this paper further uses the cross-terms of financialization and monetary policy for comparative research. Considering the possible time lag of monetary policy, this paper takes the latitudinal second-order monetary policy dummy variable as the main research object.

Table 6 reports the estimated results. It can be found that both monetary policy indicators of currency1 and currency 2 have a significant positive impact on regional innovation, indicating that a loose monetary environment can significantly improve the level of technological innovation in each region, which can be explained by mechanisms such as a loose monetary environment that provides more credit support. After the cross-terms are included, the coefficients of fin $\times$ currency and fin $\times(1$-currency 1 indicate the different effects of financialization during the relatively loose period of monetary policy and the relative tight period. Observing the regression results, it can be seen that during the period of credit easing, the negative effects of financialization on the region are significant. This shows that a relatively relaxed environment may be beneficial to enhance the financial "reservoir effect". But overall, the "crowding out effect" caused by the loose monetary environment may be stronger, which ultimately makes the negative effect of financialization on technological innovation.

Table 6. Monetary policy and financialization.

\begin{tabular}{|c|c|c|c|c|}
\hline Model & (1) & (2) & (3) & (4) \\
\hline Dependent & innovation & innovation & innovation & innovation \\
\hline fin & $-0.049(0.033)$ & $-0.035(0.031)$ & & \\
\hline currency1 & $0.002 * *(0.001)$ & & & \\
\hline currency2 & & $0.002 * * *(0.000)$ & & \\
\hline fin*currencyl & & & $-0.080 * *(0.031)$ & \\
\hline fin $*(1$-currency 1$)$ & & & $-0.053(0.034)$ & \\
\hline fin* currency 2 & & & & $-0.078 * *(0.033)$ \\
\hline Control Variable & YES & YES & YES & YES \\
\hline Provincial Effect & YES & YES & YES & YES \\
\hline Time Effect & NO & $\mathrm{NO}$ & YES & YES \\
\hline Obs. & 210 & 210 & 210 & 210 \\
\hline
\end{tabular}

Note: $* * *, * * *$ means passing the $10 \%, 5 \%, 1 \%$ significance test respectively; The standard deviation is in brackets.

\section{Robustness Test}

The above research analysis empirically tests the impact of the improvement of financialization on regional technological innovation at the macro level. The results show that the impact is significant negative. This conclusion is still 
significant after using instrumental variables and spatial effects, and there is some heterogeneity in the location. In order to ensure the robustness of the conclusion, this paper next uses the method of replacing the explanatory variables and the estimated estimation model to check whether the existing conclusions are reliable. (1) Substitute variables: From the perspective of human capital, this paper replaces the innovative indicators with the full-time equivalents of the regionalized researchers in the logarithm to measure the regional innovation investment, which is recorded as innovation- $h$. (2) Lag variable: In order to rule out possible endogeneity, all variables are evaluated by lag one step. Replacement estimation method: Considering the possible influence of the estimation model, this paper further uses IV-GMM and IV-LIML model of limited information to estimate the impact of financialization on innovation. The instrumental variable setting is similar to the above. Table 7 reports the regression results.

Table 7. Robustness test.

\begin{tabular}{|c|c|c|c|c|}
\hline \multirow{2}{*}{ Model } & (1) & $(2)$ & (3) & (4) \\
\hline & OLS & OLS & IV-GMM & IV-LIML \\
\hline Dependent & innovation-h & innovation & innovation & innovation \\
\hline fin & $-4.958 * * *(1.354)$ & & $-0.042 * *(0.017)$ & $-0.046^{* * *}(0.018)$ \\
\hline l. fin & & $-0.050 * *(0.020)$ & & \\
\hline Kleibergen-Paap LM (p-value) & & & $17.541(0.000)$ & $17.541(0.000)$ \\
\hline Cragg-Donald Wald F & & & 25.725 & 25.725 \\
\hline Stock-Yogo-10\% & & & 19.93 & 8.68 \\
\hline Sargan-Hansen J (p-value) & & & $1.609(0.205)$ & $1.609(0.205)$ \\
\hline Control Variable & YES & L. YES & YES & YES \\
\hline Provincial Effect & YES & YES & YES & YES \\
\hline Time Effect & YES & YES & YES & YES \\
\hline Obs & 240 & 240 & 180 & 180 \\
\hline
\end{tabular}

Note: $* * *, * * *$ means passing the $10 \%, 5 \%, 1 \%$ significance test respectively; The standard deviation is in brackets.

The regression results in Table 7 show that after controlling the provincial effect and time effect, the level of financialization in different regions still has a significant on regional innovation, which measured on human capital, and the significant level is above $5 \%$. In addition, after using the variable lag, IV-GMM, and IV-LIML estimation methods, the results are still consistent, indicating that the negative impact is stable.

\section{Conclusions and Implications}

This paper uses the provincial panel data of 30 regions in China from 2008 to 2016 to theoretically and empirically examine the impact of regional financialization on regional innovation activities. At the same time, on the basis of the spread of financialization, the impact in surrounding areas is verified. Further, this paper examines how monetary policy can further influence regional innovation activities through financial channels. In general, based on the existing literature, this paper analyzes the mechanism and consequences of the impact of financialization on regional innovation activities from a macro level. The empirical results show that the rising level of financialization inhibits the level of technological innovation in the region. After considering the possible spatial effects of the model, the negative impact is still significant. After examining the heterogeneity of location, it is found that the negative effect of financialization in the eastern provinces of China is the strongest. The loose monetary policy has actually further worsened the negative impact of financialization on innovation activities. In addition, considering the policy environment, loose monetary policy has actually further worsened the negative impact of financialization on innovation activities. Finally, after using substitution variables, hysteresis variables, and replacing the estimation method, the results are still robust.

This article has certain policy implications: First, governments at all levels need to pay attention to the problem of excessive financialization. The excessive financialization will cause the real economy being divisive, which will eventually lead to the collapse of the asset bubble and the economic crisis; Secondly, financialization may "squeeze out" innovative investment in the region. Therefore, the government needs to strengthen financial investment supervision, control financial asset investment behavior of corporate, and guide funds back to innovative investment. Third, monetary policy is actually prone to worsen the negative effects of financialization on innovation, how to formulate effective monetary policies, and weaken the possible negative consequences of financialization, posing challenges for government departments and central banks.

\section{References}

[1] Song Jun, Lu Wei. The U-shaped Relationship between Non-monetary Financial Assets and Operating Rate of Return_-Evidence from Financialization of China's Listed Non-financial Companies [J]. Financial Research, 2015 (6):111-127.

[2] Xie Jiazhi, Wang Wentao, Jiang Yuan. Manufacturing Finance, Government Control and Technology Innovation [J]. Economics, 2014 (11): 78-88.

[3] Stockhammer E. Financialisation and the Slowdown of Accumulation [J]. Cambridge Journal of Economics. 2004. 28 (5): 719-741. 
[4] Stockhammer E, Grafl L. Financial Uncertainty and Business Investment [J]. Review of Political Economy, 2010, 22 (4): 551-568.

[5] Huang Qunhui. On the Development of China's Real Economy in the New Era [J]. China Industrial Economy, 2017 (9): 5-24.

[6] Tadesse S. Financial Architecture and Economic Performance: International Evidence [J]. Journal of Financial Intermediation, 2002, 11 (4):429-454.

[7] Freeman R B. It's financialization! [J]. International Labour Review, 2010, 149 (2):163-183.

[8] Bhaduri A. A Contribution to the Theory of Financial Fragility and Crisis [J]. Cambridge Journal of Economics. 2011. 35 (6): 995-1014.

[9] Dore R. Financialization of the global economy [J]. Industrial \& Corporate Change, 2009, 17 (6):1097-1112.

[10] González, Ignacio, Sala H. Investment Crowding-Out and Labor Market Effects of Financialization in the US [J]. Scottish Journal of Political Economy, 2014, 61 (5):589-613.

[11] Zhang Jun, Jin Wei. Re-testing of China's Financial Deepening and Productivity Relationship: 1987-2001 [J]. Economic Research, 2005 (11): 34-45.

[12] Smith C W, Stulz R M. The Determinants of Firms' Hedging Policies [J]. Journal of Financial \& Quantitative Analysis, 1985 , $20(4): 391-405$.

[13] Gehringer A. Growth, productivity and capital accumulation: The efforts of financial liberalization in the case of European integration [J]. International Review of Economics \& Finance. 2013. 25 (0):291-309.

[14] Ang J B. Does Foreign Aid Promote Growth? Exploring the Role of Financial Liberalization [J]. Review of Development Economics, 2010, 14 (2):197-212.

[15] Epstein G. Financialization and the global economy [J]. Nimmo, 2005.

[16] Orhangazi Ö. Financialisation and capital accumulation in the non-financial corporate sector: A theoretical and empirical investigation on the US economy: 1973-2003 [J]. Mpra Paper, 2008, 32 (6):863-886.

[17] Kotz, D. M. The Financial and Economic Crisis of 2008: A Systemic Crisis of Neoliberal Capitalism [J]. Review of Radical Political Economics, 2009, 41 (3):305-317.

[18] Brenner R. What is good for Goldman Sachs is good for America: The origins of the present crisis [J]. Institute for Social Science Research Working Paper Series. 2009.

[19] He Wei, Xu Longbing. The Path and Influence of Industrial Capital's Infiltration into Financial Capital — Based on the Study of Capital Market "Golding" [J]. Journal of Finance and Economics, 2012, 38 (02):81-90.

[20] Mccahery J A, Sautner Z. Institutional Investor Preferences and Executive Compensation [J]. Social Science Electronic Publishing, 2012, 2012-004 (1):241-254.

[21] Getina K K., A Preda. The Oxford Handbook of the Sociology of Finance [M]. 2012. Oxford University Press.
[22] Frédéric Lordon. Willing Slaves of Capital: Spinoza and Marx on Desire., trans., Gabriel Ash [M]. London: Verso, 2014.

[23] Zhang Yu, Zhang Chen, Cai Wanhuan. Political Economic Analysis of China's Economic Model [J]. China Social Sciences, 2011 (3): 69-84.

[24] Chen Shihua, Lu Changchong. Emergency Management and M\&A Premium Decision-making among Enterprises_-An Empirical Study Based on Inter-Organization Imitation Theory [J]. Management World, 2013 (05):144-156.

[25] Zhao Qinglu, Kong Xiang, Hou Qingchuan. Monetary Policy, Investment Efficiency of Private Enterprises and Company Option Value [J]. Economic Research, 2012, 47 (05):96-106.

[26] Ye Kangtao, Zhu Jigao. The austerity of the money and the allocation of credit resources [J]. Management World, 2009 (01):22-28

[27] Rao Pingui, Jiang Guohua. Monetary Policy, Credit Resource Allocation and Enterprise Performance [J]. Management World, 2013 (03): 12-22.

[28] Zhai Xiaosheng. Financing Sources and Smoothing Mechanism of Innovative Investment in Chinese Listed Companies [J]. World Economy, 2013 (4):138-159.

[29] Wang Hongjian, Cao Yuqiang, Yang Qing, Yang Zheng. The Promotion of Financialization of Entity Enterprises or the Inhibition of Enterprise Innovation_-Based on the Empirical Study of Chinese Manufacturing Listed Companies [J]. Nankai Management Review, 2017, 20 (01):155-166.

[30] Aghion P., N Bloom., Blundell R., Griffith R., Howitt P. Competition and Innovation: An Inverted U Relationship [J]. Quarterly Journal of Economics. 2005. 120 (2): 701-728.

[31] Hashmi A R. Competition and Innovation: The Inverted-U Relationship Revisited [J]. Social Science Electronic Publishing. 2011. 95 (5): 1653-1668.

[32] King R G., Levine R. Finance and Growth: Schumpeter might be right $[\mathrm{J}]$. Quarterly Journal of Economic. 1993. (108): 717-738.

[33] Levine R., Zervos S., Stock Markets. Bank and Economic Growth [ J ] . American Economic Review. 1998. 88 (3):537-558.

[34] Palley T I. Financialization: What it is and Why it Matters [J]. Social Science Electronic Publishing, 2007, 26 (9):9-15.

[35] Xu Hao, Feng Tao, Zhang Lei. Financial Development, Government Intervention and Capital Allocation Efficiency_—_Based on China's Empirical Analysis from 1978 to 2013 [J]. Shanghai Economic Research, 2015 (10):40-48.

[36] Zhang Chengsi, Zhang Buzhen. Re-discussion on Finance and Real Economy: The Perspective of Economic Financialization [J]. Economic History, 2015 (06): 56-66.

[37] Zhu Jigao, Lu Zhengfei. Monetary Policy, Enterprise Growth and Changes in Cash Holdings [J]. Management World, 2009 (3): $152-158$. 